\title{
Polyethylene glycol reduces the net flux of branched-chain amino acids across the mammary gland in ewes fed sulla*
}

\author{
N.C. Roy ${ }^{1}$, B.R. Sinclair, B. Treloar, J.S. Peters and W.C. McNabb ${ }^{1}$ \\ Nutrition and Behaviour Platform, AgResearch Limited, Grasslands Research Centre \\ Palmerston North, New Zealand
}

\begin{abstract}
Six lactating ewes were orally drenched each day with polyethylene glycol to remove the effects of the condensed tannins in sulla (Hedysarum coronarium) and six other ewes (control) received a drench of water. The treatments were started 28 days prior to the measurement period. At week 6 of lactation, net absorption of branched-chain amino acids in the mesenteric vein was not affected by PEG. Valine and leucine were released by the liver in the PEG ewes and extracted in the control ewes. The net mammary uptake of isoleucine and leucine was lower in the PEG ewes.
\end{abstract}

KEY WORDS: sheep, condensed tannins, branched-chain amino acid, net flux, tissue beds

\section{INTRODUCTION}

A moderate concentration of condensed tannins (CT) in the diet can reduce the degradation of dietary protein in the rumen (McNabb et al., 1996) and can increase the apparent intestinal absorption of essential amino acids (EAA), especially essential branched-chain AA (BCAA; Bermingham et al., 2001). Uptake of BCAA by the mammary gland is usually in excess of that required for milk protein synthesis and this excess is used for other important mammary functions such as the synthesis of non-essential AA (Pacheco et al., 2003). Increased milk production and protein concentration was observed in ruminants fed fresh CTcontaining forages, suggesting that these legumes may have potential as forages for improving dairy production (Woodward et al., 1999).

Our hypothesis was that the CT in sulla (Hedysarum coronarium) would increase the partitioning of BCAA to the mammary gland in lactating ewes.

\footnotetext{
* Supported by the New Zealand Foundation for Research Science and Technology

${ }^{1}$ Corresponding authors: e-mail: nicole.roy@agresearch.co.nz and warren.mcnabb@agresearch.co.nz
} 
Polyethylene glycol (PEG) binds and inactivates CT and the effects of CT can be elucidated by comparing the net flux of BCAA across the mesenteric-drained viscera (MDV), portal-drained viscera (PDV) and liver of ewes fed fresh sulla and dosed with PEG with that of ewes that had not received PEG (CT active).

\section{MATERIAL AND METHODS}

Two weeks postpartum, twelve ewes were prepared with catheters in the mesenteric artery and in the mesenteric, portal and hepatic veins (Huntington et al., 1989) and a transonic flow probe (6R) was fitted around the pudic artery to measure mammary blood flow. A catheter was also inserted into the caudal superficial epigastric (mammary) vein two days prior blood sampling. All ewes were then offered fresh sulla $\left(1500 \mathrm{~g} \mathrm{DM} \mathrm{d}^{-1} ; 80 \mathrm{~g} \mathrm{CT} \mathrm{d}^{-1}\right)$. Six ewes were orally drenched each day with PEG (160 $\mathrm{g} \mathrm{d}^{-1}$ in water; CT inactive) to remove the effects of CT and six ewes (Control; CT active) received a drench of water.

Six weeks postpartum, sodium para-aminohippurate (pAH) was infused for $7 \mathrm{~h}$ into the mesenteric vein to measure blood flow across the total splanchnic tissue (TSP = PDV + liver; Huntington et al., 1989). Mammary blood flow was measured continuously during this period. Plasma was obtained from blood samples collected from the blood vessels mentioned previously for measuring AA (Pacheco et al., 2003) and pAH concentration (Huntington et al., 1989). One control ewe died for reasons not related to the treatment. Plasma flow and net BCAA flux results were subjected to the SAS GLM procedure according to a block design. Treatment differences were declared as significant and trend at a probability less than 0.05 and 0.10 , respectively.

\section{RESULTS}

The plasma flows across the MDV, PDV and TSP were similar between treatments (Roy et al., companion paper) but there was a trend for reduced mammary blood flow in the PEG ewes (Control: 362 vs PEG: 260 (SED 40) mL/ $\mathrm{min})$. The concentration of BCAA in all blood vessels tended to be lower in PEG ewes, but this was significant (or trend) only for mesenteric artery, mesenteric and portal veins (except for leucine, Table 1). The net appearance of BCAA in the mesenteric drainage was not affected by PEG. Lower net appearance of BCAA in the portal vein was observed in PEG ewes but this was not significant (Table 1). Inflow of BCAA to the liver was lower in PEG ewes (data not shown, $\mathrm{P}<0.10$ ). All of the BCAA were released by the liver in the PEG ewes and extracted in the control ewes significantly for valine and leucine (Table 1). A similar net release of BCAA by the TSP was observed with both treatments. The net uptake of BCAA by the mammary gland was lower in the PEG ewes (Table 1). 
Table 1. Effect of polyethylene glycol on the partitioning of branched-chain amino acids across the mesenteric-drained viscera (MDV), portal-drained viscera (PDV), liver and total splanchnic tissue (TSP) in lactating ewes fed sulla ${ }^{1}$

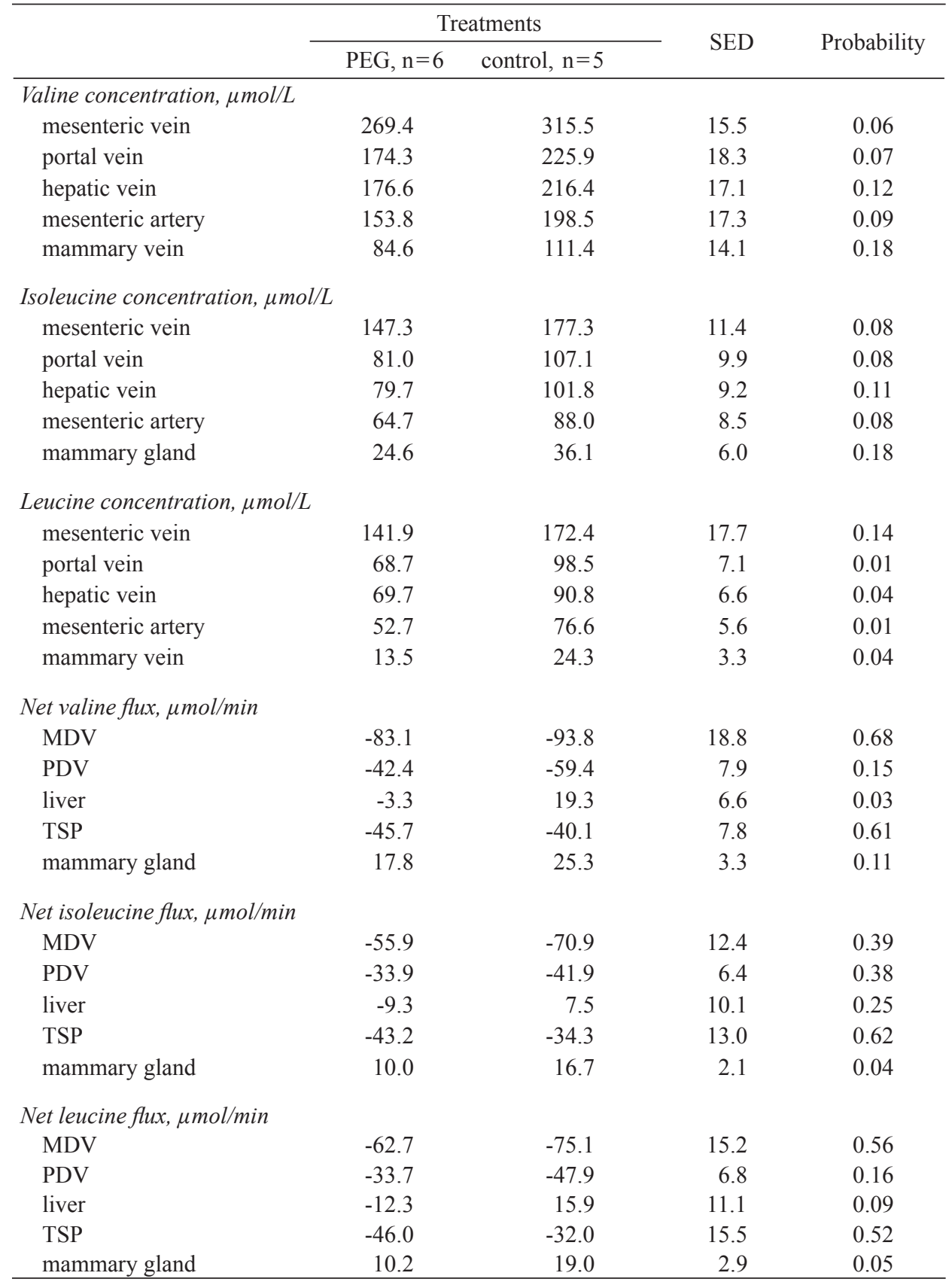

${ }^{1}$ positive values indicate net uptake and negative values, net production from the organ 


\section{DISCUSSION}

Our study shows that the intra-luminal addition of PEG to lactating ewes fed a CT-containing plant sulla decreased the net uptake of BCAA by the mammary gland. This effect of PEG does not seem to be due to a lower TSP release of BCAA. Despite the portal absorption of valine and leucine being $40 \%$ higher without PEG, the liver appeared to extract most of the additional inflow. This result does not support higher BCAA concentration found in the peripheral circulation of the control ewes. Higher mammary plasma flow and peripheral BCAA concentration could explain the elevated mammary uptake in control ewes (CT active). This agrees with results showing that BCAA are taken up by the bovine mammary gland not only for milk protein synthesis but also for oxidation or synthesis of metabolites important for mammary function (Pacheco et al., 2003).

The trends observed with our absorption data are in agreement with previous results where the apparent intestinal BCAA absorption was higher in control sheep compared to PEG (CT inactive) sheep (Bermingham et al., 2002). Higher variation associated with the measurement of the MDV flow might have prevented the detection of significant differences.

\section{CONCLUSIONS}

These results establish that intra-luminal addition of PEG to lactating ewes fed the CT-containing plant sulla decreased the net uptake of BCAA by the mammary gland by, at least partly, down-regulating mammary blood flow.

\section{REFERENCES}

Bermingham E.N., Hutchinson K.J., Revell D.K., Brookes I.M., McNabb W.C., 2001. The effects of condensed tannins in sainfoin (Onobrychis viciifolia) and sulla (Hedysarum coronarium) on the digestion of amino acids in sheep. Proc. N.Z. Soc. Anim. Prod. 61, 116-119

Huntington G.B., Reynolds C.K., Stroud B.H., 1989. Techniques for measuring blood flow in splanchnic tissues of cattle. J. Dairy Sci. 72, 1583-1595

McNabb W.C., Waghorn G.C., Peters J.S., Barry T.N., 1996. The effect of condensed tannins in Lotus pedunculatus on the solubilization and degradation of ribulose-1,5-bisphosphate carboxylase (EC 4. 1. 1. 39; Rubisco) protein in the rumen and the sites of Rubisco digestion. Brit. J. Nutr. 76, 535-549

Pacheco D., Tavendale M.H., Reynolds G.W., Barry T.N., Lee J., McNabb W.C., 2003. Whole-body fluxes and partitioning of amino acids to the mammary gland of cows fed fresh pasture at two levels of intake during early lactation. Brit. J. Nutr. 90, 271-281

Woodward S.L., Auldist M.J., Laboyrie P.J., Jansen E.B.L., 1999. Effect of Lotus corniculatus and condensed tannins on milk yield and milk composition of dairy cows. Proc. N.Z. Soc. Anim. Prod. 59, 152-155 